Bull. Fac. Agric., Cairo Univ., 68: 371-383 (2017).

\title{
CONVERTED OLIVE MILL WASTES TO COMPOST TEA WITH BIOLOGICAL TREATMENT AND ITS IMPACT ON GROWTH AND PRODUCTIVITY OF MANZANILLO OLIVE TREES
}

(Received: 3.12.2017)

\author{
By \\ Sh. A. Shaheen, A. S. El-Soda and A. F.M. Abd-Elwahab* \\ Department of Olive and Semi-Arid Zone Fruits, Horticulture Research Institute, \\ and "Department of Microbiology, Soils, Water and Environment Research Institute, \\ Agricultural Research Center, Egypt
}

\begin{abstract}
The current study has been carried out through two successive seasons (2013 and 2014) on 12 years old Manzanillo olive trees in a private orchard located $50 \mathrm{~km}$ of Cairo-Alexandria road in the north west of Egypt. The main objective of this study was to convert olive mill wastes [pomace and olive vegetable water (OVW)] to compost tea (CT) and studying their effect on growth and productivity of olive trees. Compost tea (CT) was prepared by soaking the mixture of compost and olive pomace $(2: 1)$ in either water or the combination of water with olive vegetable water at different rates (25\% or 50\%). Four microorganisms (Serratia marcescens, Pseudomonas fluorescens, Phanerochate chrysosporium and Trichoderma virdi) were used in preparing compost tea. Data exerted that the treatment with CT + microorganisms gave the highest shoot length, number of leaves, fruit diameter, flesh/fruit weight. While, using the mixture of compost tea (50\%) and olive vegetable water (50\%) and incubated with microorganisms recorded the highest leaf area, flowering density, perfect flower (\%), fruit set (\%), yield, olive oil content, leaf nitrogen and potassium content as well as the highest net profit. Thus, it could be recommended, under the same conditions of this study, to use converted olive mill wastes to compost tea (CT) at the rate of 50\% $+50 \%$ olive vegetable water $(\mathrm{OVW})+$ microorganisms to increase the productivity of Manzanillo olive trees and the net income, which in turn reduces the amount of fertilizer and environmental pollution caused by these wastes.
\end{abstract}

Key words: olive, pomace, olive vegetable water, compost tea, microorganisms.

\section{INTRODUCTION}

Olive (Olea europaea L.) is an important perennial crop and it is one of the oldest cultivated trees in the history of the world, about thousands years ago. Olive tree is mentioned in several verses of Quran and in holy books. It is widely distributed tree grown in many arid zones and native to all the countries around the Mediterranean region that provides $97 \%$ of olive production of the world. (Aragon and Palancar 2001; Tuck and Hayball, 2002; Aruoma, 2003). Olive oil industry generates large amount of oily waste designated raw olive pomace (lignocelluloses waste) and olive vegetable water (OVW) that contains a large amount of both organic and inorganic matter. So, it is a very valuable product from both economic and environmental points and an asset that reduces the use of chemical fertilizer, provides protection from erosion, and improves soil fertility and bacterial activity.

There is an expansion in worldwide attention for the utilization of natural liquid and beneficial microorganisms to help organic horticulture and sustainable agriculture (Noval and Rezk, 2009). Compost tea is a liquid fertilizer produced by mixing compost with water and culturing for a defined period. The diverse microbial profile in compost tea helps the plant leaves to absorb nutrients from the air, helping the plant root system to extract nutrients from the soil and recycling the organic matter (Hargreaves et al., 2009). An essential reason of delivering compost tea is to exchange microbial biomass, fine particulate natural issue and dissolvable substance of compost into a watery stage that can be utilized to plant surfaces and soils (Pane et al., 2012). A divers array of bacteria has been shown to promote plant growth. (Vessey 2003; Rasouli et al., 2008; Verma et al., 2010). 
Serratia marcescens and Pseudomonas fluorescensare are a symbiotic $\mathrm{N}_{2}$ fixation, able to produce plant hormones, solubilization of inorganic phosphate and mineralization of organic phosphate and other nutrients (Malik and Sindhu, 2011 and Page et al., 2012). Phanerocheate chysosporium is identified as fungal species which has high potentialities for removing phenolic compounds and degraded lignin and cellulose in olive pomace (Malik et al., 2009; Mohammed, 2011). Trichoderma viridi, species of fungus, has an important role in helping plants to cope with environmental stresses such as drought, water logging, nutritional stress and production of enzymes, especially celluloses (Jose et al., 2011). In fact, like all agricultural tools, compost tea is not a silver bullet for solving widespread problems associated with depleted soils or unsustainable farming practices, but has the important role that can be used as a carrier to fine plant nutrients, help plant leaves to absorb nutrients and is considered as a way to build soil structure when applied as drench and optimizes the soil $\mathrm{PH}(\mathrm{Ha}$ et al., 2008 and Pane et al., 2012). So, preparing compost tea by using olive vegetable water and olive pomace is important to improve the fertility statues and productivity (Blanquez et al., 2002; Paredes et al., 2005; Paraskeva et al., 2006; Lefi et al., 2009).

The aim of the present study was to transfer technology using wastes of olive oil extraction (vegetative water and olive pomace) in the preparation of compost tea with biological treatment on the agriculture land and to high light the advantage of these practices on growth, flowering, crop and oil quality and yield.

\subsection{Field practices}

\section{MATERIALS AND METHODS}

Field experiments were conducted during two successive seasons (2013 and 2014) on 12 year old Manzanillo olive trees grown in a private orchard located 50 Kilometer from CairoAlexandria desert road to investigate the conversion of olive wastes (pomace \&vegetable water) to compost tea with biological treatment and studying their effect on vegetative growth, flowering, leaf minerals content, fruit properties, yield and oil content. The trees were grown in sandy soil at the distance of $5 \times 5$ meters apart under drip irrigation system. The selected trees were nearly uniform, vigor growth and free from pathological and physiological disorders. The trees received the same cultural managements (irrigation, fertilization, control weed, pests, and diseases). Farm fertilization (compost and mineral fertilization) was applied to the trees according to recommendations of the Ministry of Agriculture, Egypt. Compost was applied at the second week of November in two parallel ditches of $100 \times 40 \times 30 \mathrm{~cm}$, (length, width and depth, respectively). The ditches surrounded the tree from two directions in the end of canopy shade. Mineral fertilization during season was added at the rate of $100 \mathrm{gm}$ nitrogen $+270 \mathrm{gm}$ potassium $+500 \mathrm{gm}$ of $\mathrm{MgSO}_{4}(9.6 \% \mathrm{Mg})+$ $250 \mathrm{gm}$ sulphur $+250 \mathrm{gm}$ boron (Borax)/ tree. Physical and chemical properties of the compost (Table 1) were analyzed according to (Paredes et al., 2005). The soil was analyzed (Table 2) according to (Chapman and Pratt, 1978). Irrigation water analysis is conducted in the Soil and Water Research Institute (SWRI), ARC, as shown in Table (3).

Table (1): Physical, chemical and microbiological analysis of compost.

\begin{tabular}{|l|c|}
\hline Parameters & Compost \\
\hline PH & 7.12 \\
\hline EC $(\mathrm{ds} / \mathrm{m})$ & 4.89 \\
\hline Organic carbon\% & 23.20 \\
\hline Organic matter \% & 39.90 \\
\hline Total N $(\%)$ & 1.95 \\
\hline Total P (\%) & 0.45 \\
\hline Total K (\%) & 2.64 \\
\hline NH4 -N (ppm) & 188 \\
\hline NO3 -N $(\mathrm{ppm})$ & 215 \\
\hline Total-N $(\mathrm{ppm})$ & 403 \\
\hline Total count of bacteria $(\mathrm{cfu} / \mathrm{g})$ & $3.3 \times 10^{7}$ \\
\hline Total count of fungi $(\mathrm{cfu} / \mathrm{g})$ & $1.2 \times 10^{5}$ \\
\hline $\begin{array}{l}\text { Total count of actinomycetes } \\
\text { (cfu/g) }\end{array}$ & $1.3 \times 10^{6}$ \\
\hline
\end{tabular}

Table (2): Physical and chemical analysis of the soil.

\begin{tabular}{|l|c|l|c|}
\hline \multicolumn{2}{|c|}{ Particles size distribution } & \multicolumn{2}{c|}{ Chemical analysis } \\
\hline Coarse sand (\%) & 4.45 & $\mathrm{EC} \mathrm{dS} / \mathrm{m}(1: 2.5)$ & 4.40 \\
\hline Fine sand (\%) & 76.35 & $\mathrm{pH}(1: 2: 5)$ & 8.46 \\
\hline Silt (\%) & 12.9 & Organic matter (\%) & 0.19 \\
\hline Clay (\%) & 6.30 & Organic carbon (\%) & 0.11 \\
\hline Texture & $\begin{array}{c}\text { Loamy } \\
\text { sand }\end{array}$ & \multicolumn{2}{|c|}{ Total nutrients $\mathbf{~ m g / k g}$} \\
\hline \multicolumn{2}{|c|}{ Total nutrients $\mathbf{~ m g / 1 0 0 g}$} & \multicolumn{2}{|c|}{1.35} \\
\hline $\mathrm{N}$ & 0.13 & $\mathrm{Mn}$ & 0.46 \\
\hline $\mathrm{P}$ & 0.40 & $\mathrm{Zn}$ & 1.60 \\
\hline $\mathrm{K}$ & 7.40 & $\mathrm{Fe}$ & \\
\hline
\end{tabular}


Table (3): Chemical analysis of well's water

\begin{tabular}{|c|c|c|c|c|c|c|}
\hline $\begin{array}{l}\text { E.C.w } \\
\text { mmhos }\end{array}$ & $\begin{array}{l}\text { TSS } \\
\text { ppm }\end{array}$ & pH & \multicolumn{4}{|c|}{ Cations (meq/l) } \\
\hline \multirow{5}{*}{0.84} & \multirow{5}{*}{537.6} & \multirow{5}{*}{7.4} & $\mathrm{Mg}^{++}$ & $\mathrm{Ca}^{++}$ & $\mathbf{K}^{+}$ & $\mathrm{Na}^{+}$ \\
\hline & & & 2 & 4 & 0.2 & 2.1 \\
\hline & & & \multicolumn{4}{|c|}{ Anions (meq/L) } \\
\hline & & & $\mathrm{SO}_{4}^{-}$ & $\mathrm{Cl}^{-}$ & $\mathrm{HCO}_{3}^{-}$ & $\mathrm{CO}_{3}$ \\
\hline & & & 0.2 & 6.1 & 2 & Few \\
\hline
\end{tabular}

\subsection{Treatments}

Forty-two nearly uniform trees were selected for this study. The experiment included 7 treatments represented by 3replicates ( 2 trees per each).

The treatments were arranged as follows

1) Control (adopted fertilization program in the farm)

2) Compost tea $100 \%$

3) Compost tea $100 \%+*$ Microorganisms

4) $75 \%$ Compost tea $+25 \%$ Olive vegetable water

5) $75 \%$ Compost tea $+25 \%$ Olive vegetable water+ *Microorganisms

6) $50 \%$ Compost tea $+50 \%$ Olive vegetable water

7) $50 \%$ Compost tea $+50 \%$ Olive vegetable water $+*$ Microorganisms

* Microorganisms (Serratia marcescens and

Pseudomonas fluorescens)

Farm mineral fertilization was usually applied for all the trees in this orchard. The control trees received $50 \mathrm{Kg}$ /tree of compost, while, other trees treated with compost tea (T2-T7) received half the amount of farm compost fertilizer $(25 \mathrm{~kg})$. Compost tea was added as soil application (5 1/tree) at the end of canopy shade each two weeks during the period from the first week of January till the end of fruit set.

\subsection{Preparing compost tea}

\subsubsection{The following materials were involved}

- Compost:A mixture of plant manure compost and olive pomace by the ratio of $(2: 1)$.

- Olive mill wastes [pomace (OPW) and vegetable water $(\mathrm{OVW})]$ : Each of $\mathrm{OPW}$ and OW was collected during the late fall and winter season from olive oil three phase extraction in a private farm that the experimental was set. The main traits of physical and chemical properties were determined according to (Berrin et al., 2008) as shown in Table (4).

- Microorganisms: The strains Serratia marcescens, Pseudomonas fuorescens, Phanerochate chrysosporium and Trichoderma virdi used in this study were supplied by Microbiology Dept., Soil, Water and Environment Research Center, ARC), Giza, Egypt, according to (Atlas 1995).

2.3.2. Method of preparing compost tea and enriched compost tea

For preparing compost tea /tree, $500 \mathrm{gm}$ of compost (plant manure compost and olive pomace at the ratio $2: 1$ ) had been soaked with:

- Either water at the rate of 51 (T2\&T3).

- A mixture of water and OVW at the rate of 3.751 of water+1.25 1 of OVW (T4 \& T5).

- A mixture of water and OVW at the rate of 2.51 of water +2.51 of OVW (T6 \& T7).

- $5 \mathrm{~cm}$ of Trichoderma and Phanerochate inoculums were added to the ingredient of compost tea in a shaded place for 14 days with a suitable daily stirring in a plastic barrel (Ingham, 2005). Aeration was done at the rate of $4 \mathrm{hr} /$ day in the intermittent periods. After elapsing of incubation time, the liquid mixture was filtered by100 mesh screen (T2:T7).

- Then $5 \mathrm{~cm}$ of Serratia and Pseudomonas (as a liquid carrier) were added to compost tea (Bio-enriched compost tea) for 7 days to the treatments (T3, T5 \& T7) (Page et al., 1982), where all treatments became ready to use.

\section{4. Measurements}

2.4.1. Physical and chemical analysis of treated compost tea and OVW with microorganisms: Physical and chemical properties of treated compost tea and OVW with microorganisms were determined at Soil and Water Research Institute (SWRI), ARC, Giza, Egypt.

2.4.2. Vegetative growth characteristics: At the end of each growing season, the following parameters were recorded:

- Average shoot length $(\mathrm{cm})$.

- Leaf density $=$ the number of leaves / shoot

Table (4): Physical and chemical analysis of olive pomace and olive vegetable water.

\begin{tabular}{|l|c|c|c|c|c|c|c|c|}
\hline \multirow{2}{*}{ Olive waste } & \multicolumn{7}{|c|}{ Parameters } \\
\cline { 2 - 9 } & $\mathbf{P H}$ & $\begin{array}{c}\text { EC } \\
(\mathbf{d s} / \mathbf{m})\end{array}$ & $\begin{array}{c}\text { Organic } \\
\text { carbon \% }\end{array}$ & $\begin{array}{c}\text { Organic } \\
\text { matter \% }\end{array}$ & $\begin{array}{c}\text { Total } \\
\mathbf{N}(\%)\end{array}$ & $\begin{array}{c}\text { Total } \\
\mathbf{P}(\%)\end{array}$ & $\begin{array}{c}\text { Total } \\
\mathbf{K}(\boldsymbol{\%})\end{array}$ & $\begin{array}{c}\text { Polyphones } \\
(\mathbf{p p m})\end{array}$ \\
\hline Olive pomace & 6.25 & 2.40 & 29.36 & 50.50 & 0.79 & 0.05 & 1.20 & 10000 \\
\hline Olive Vegetative water & 5.07 & 5.50 & 11.01 & 18.94 & 0.40 & 0.0002 & 0.05 & 8500 \\
\hline
\end{tabular}


and calculated per meter.

- Leaf area $\left(\mathrm{cm}^{2}\right)$ : using a planimeter according to (Aly, 2005).

2.4.3. Leaf minerals content: At the first week of August of each season, leaf samples were taken from mid of the current of growing shoots (Piper, 1950), washed with water then dried by air at $70{ }^{\circ} \mathrm{C}$ till constant weight and finally ground. Thereafter, the following determinations were carried out in the acid digested solutions as reported by (Van Shouwonburg,1968).

- Nitrogen was determined by the Micro kjeldahl method (Pregl, 1945).

- Phosphorous was estimated by the method described by (Murphy and Riely, 1962)

- Potassium was flame-photometerically determined according to (Brown and Lilleland, 1946).

\subsubsection{Flowering parameters}

-Flowering dates: Date of the inflorescence emergence was recorded as the first sign of inflorescence parts appeared.

- Blooming dates: Beginning and end of flowering dates were recorded when $25 \%$ and $75 \%$, respectively of the total flowers opened (Hegazi, 1970).

-Blooming periods: Calculated as the days between beginning of flowering and ending of blooming (Mofeed, 2002).

- Inflorescence length (cm): Thirty inflorescences were randomly taken from each replicate and the length of their axis was measured.

-Flowering density: Average number of inflorescences per shoot was recorded and calculated per meter.

- Perfect flower (\%):Determined according to Rallo and Fernández-Escobar (1985)

Perfect flowers $(\%)=$ No. of perfect flowers / No. of total flowers x 100

\subsubsection{Fruiting}

- Fruit set on each replicate tree was recorded after 21 days from full bloom according to (Rosa et al., 2008) and their percentages of No. of total flowers /tree were calculated.

- The average yield $(\mathrm{kg})$ was recorded at ripe stage (olive with superficial pigmentation on more that $50 \%$ of the skin) for each replicate tree.

2.4.6. Fruits physical characteristics: Fifty fruits at ripe stage were randomly selected in both seasons from each replicate tree to study physical and chemical characteristics of fruits in different treatments according to the following basis:

- Fruit characters: length $(\mathrm{cm})$, diameter $(\mathrm{cm})$ and weight (g.).

- Stones were extracted from the selected fruits to determine their length $(\mathrm{cm})$, diameter $(\mathrm{cm})$, weight $(\mathrm{g})$ and flesh/stone ratio.

- Flesh/fruit weight percentage was calculated according to the following equation:

Flesh weight $(\mathrm{g})=$ average fruit weightaverage stone weight.

Flesh/fruit $(\%)=$ Flesh weight/ average fruit weight $\mathrm{x} 100$ according to (Fouad et al., 1992).

2.4.7. Fruit oil content (\%): Fruit oil content as dry weight was determined according to (A.O.A.C 1995) method by extraction the oil from the dried fruits with soxelt fat extraction apparatus using petroleum ether $60-80^{\circ} \mathrm{C}$ of boiling point.

2.4.8. Economic evaluation: Economic evaluation was calculated according to Heady and Dillon (1961) as follows:

- Cost of fertilizing with compost $/$ Fadden $=$ number of trees $(120) \times$ amount of compost /tree $(50 \mathrm{~kg}) \times$ price of compost $(250 \mathrm{~L}$. E/ ton) $=1500$ L.E

- Total cost of half amount of fertilizing with compost $/$ Fadden $=750$ L.E

- Quantity of compost tea used/year [number of soil drench (8) $\times$ amount of added compost tea $(6001 /$ Fadden $)]=48001$ /Fadden

- Cost of the compost tea unit (tank+ pipes pvp+ air pump) $=500$ L.E.

- Cost of microorganisms/ Fed $=$ price of $1(10$ L.E.) $\mathrm{x}$ number of microorganisms (4) $\mathrm{x}$ number of additions (8).

- Fixed expenses $=($ mineral fertilization, labor, pesticides and others) $=2300$ L.E.

- Total cost $=$ sum of all costs.

- Total gross income $=$ average yield of two seasons $(\mathrm{kg}) /$ Fadden $\times$ total price (3 L.E.)

- Gross margin = total gross income - total cost

\subsection{Statistical analysis}

All data were tested for treatments effects on analyzed parameters by the one-way analysis of variance (ANOVA), according to (Snedecor and Cochran, 1980). Differences between treatments were compared by Duncan's multiple range tests SAS (SAS, 1994). 


\section{RESULTS AND DISCUSSION}

3. 1. Effect of microorganisms on physical and chemical analysis of compost tea and OVW.

The results in Table (5) showed that there were a decrease in $\mathrm{PH}$, organic carbon, and organic matter, while there were increases in the available of phosphor and potassium. The decrease of PH was observed in the treatments of compost tea with olive vegetable water that inculcated with microorganisms comparing with others. This decrease was probable due to the addition of olive vegetable water, while a decrease of organic carbon percentage because of converting to $\mathrm{CO}_{2}$ as result of decomposition. Moreover, organic matter declined gradually specially in the treatments of compost tea with olive vegetable water inculcated with microorganisms. This could be attributed to degradation into simple compound (Hargreaves et al., 2009). Total carbon losses are usually associated with a decrease in organic matter due to the mineralization ( which is directly related to respiration). More of organic $\mathrm{N}$ disappears by increasing of the microbial activity. The increase of $\mathrm{P}$ and $\mathrm{K}$ due to the role of Serratia marcescens and Pseudomonas fluorescensare for producing plant hormones and organic acids which hold $\mathrm{Ca}^{++}$, that solubilize inorganic phosphate, and mineralize phosphate and other nutrients (Page et al., 2012; Malik \& Sindhu, 2011).

\subsection{Vegetative growth parameters}

With regard to the collected data in Table (6), the longest shoots $(31.7 \& 33.45 \mathrm{~cm})$ and No. of leaves (168.15 \& 172.50) were noticed with trees treated with CT + microorganisms in both seasons, respectively. While, the control was the other way around as it recorded the least values in both seasons. With respect to leaf area values, the differences between the control and other treatments in both seasons were insignificant. These results confirmed the prominent role of compost tea with microorganisms in an active state that thereby improved water nutrient uptake that leads to increase shoot length and produce more branches (Ingham, 2005). The results of El-Taweel et al. (2016) confirmed that irrigated olive trees with olive vegetable water treated with bacteria improved vegetative growth parameters. Ammar and Ben (1999); Al-Absi, (2010) declared that, using the olive wastes (OVW and OPW) showed significant increase in young shoot length, the number of new shoots and leaf area on olive trees.

\subsection{Leaf minerals content}

Response of N, P, K contents in the leaves of Manzanillo olive trees to different treatments under study are shown in Table (7). Data exerted that, the highest nitrogen percentage (1.66 and $1.80 \%)$ and potassium contents $(1.73$ and $1.66 \%)$ in both seasons, respectively, were recorded in the experimental trees treated with $50 \%$ of compost tea $+50 \%$ OVW +microorganisms. Meanwhile, there was no considerable statistical increase in leaves phosphorus content in the two studied seasons. The minimum values of leaves $\mathrm{N}$ and $\mathrm{K}$ contents were recorded by the control in both seasons.

These increases are related to the ability of

Table (5): Physical and chemical analysis of treated compost tea and OVW with microorganisms.

\begin{tabular}{|c|c|c|c|c|c|c|c|c|c|c|}
\hline \multirow[b]{2}{*}{ Treatments } & \multicolumn{10}{|c|}{ Parameters } \\
\hline & PH & $\begin{array}{c}\text { EC } \\
(\mathbf{d s} / \mathbf{m})\end{array}$ & $\begin{array}{c}\text { Organic } \\
\text { carbon \% }\end{array}$ & $\begin{array}{r}\text { Organic } \\
\text { matter\% }\end{array}$ & $\begin{array}{c}\text { Total } \\
\text { N(ppm) }\end{array}$ & $\begin{array}{c}\text { Total P } \\
(\mathbf{p p m})\end{array}$ & $\begin{array}{c}\text { Total K } \\
(\text { ppm) }\end{array}$ & $\begin{array}{c}\mathrm{NH4}-\mathrm{N} \\
(\mathrm{ppm})\end{array}$ & $\begin{array}{l}\mathrm{NO3}-\mathrm{N} \\
(\mathrm{ppm})\end{array}$ & $\begin{array}{c}\text { Total-N } \\
(\mathbf{p p m})\end{array}$ \\
\hline$* \mathbf{C T}$ & $7.15 \mathrm{a}$ & $4.42 \mathrm{f}$ & $5.92 \mathrm{~b}$ & $10.18 \mathrm{~b}$ & $97 \mathrm{c}$ & $34.49 \mathrm{~d}$ & $128.70 \mathrm{f}$ & $71.60 \mathrm{a}$ & $14.0 \mathrm{a}$ & $85.60 \mathrm{~b}$ \\
\hline $\mathbf{C T}+* *$ microorganisms & $6.50 \mathrm{~b}$ & $4.78 \mathrm{e}$ & $5.07 \mathrm{c}$ & $8.72 \mathrm{c}$ & $95 \mathrm{c}$ & $88.47 \mathrm{a}$ & $542.50 \mathrm{c}$ & $66.49 \mathrm{~b}$ & $14.31 \mathrm{a}$ & $80.80 \mathrm{c}$ \\
\hline $75 \% \mathrm{CT}+25 \% * * * \mathrm{OVW}$ & $6.91 \mathrm{a}$ & $5.08 \mathrm{~d}$ & $4.10 \mathrm{~d}$ & $7.05 \mathrm{~d}$ & $119 \mathrm{~b}$ & $31.03 \mathrm{e}$ & $301.85 \mathrm{e}$ & $66.49 \mathrm{~b}$ & $14.31 \mathrm{a}$ & $80.80 \mathrm{c}$ \\
\hline $\begin{array}{l}75 \% \mathrm{CT}+25 \% \text { OVW + } \\
\text { Microorganisms }\end{array}$ & $5.50 \mathrm{c}$ & $6.56 \mathrm{~b}$ & $3.40 \mathrm{e}$ & $5.85 \mathrm{~d}$ & $115 b$ & $49.84 \mathrm{~b}$ & $686.40 \mathrm{~b}$ & $72.38 \mathrm{a}$ & $15.43 \mathrm{a}$ & $87.81 \mathrm{a}$ \\
\hline $50 \% \mathrm{CT}+50 \% \mathrm{OVW}$ & $6.20 \mathrm{~b}$ & $5.22 \mathrm{c}$ & $9.00 \mathrm{a}$ & $15.48 \mathrm{a}$ & $129 \mathrm{a}$ & $21.32 \mathrm{f}$ & $352.80 \mathrm{~d}$ & $63.55 \mathrm{c}$ & $11.45 \mathrm{~b}$ & $75.00 \mathrm{~d}$ \\
\hline $\begin{array}{l}\mathbf{5 0 \%} \text { CT+ } 50 \% \text { OVW+ } \\
\text { Microorganisms }\end{array}$ & $5.40 \mathrm{c}$ & $7.98 \mathrm{a}$ & $4.99 \mathrm{c}$ & $8.58 \mathrm{c}$ & $125 \mathrm{a}$ & $41.20 \mathrm{c}$ & $707.70 \mathrm{a}$ & $70.70 \mathrm{a}$ & $15.64 \mathrm{a}$ & $86.34 \mathrm{ab}$ \\
\hline
\end{tabular}

Means having the same letter(s) within the same column are not significantly differ at the probability of $5 \%$ level according to Duncan's Multiple Range Test. *CT: Compost tea ** Microorganisms: (Serratia marcescens andPseudomonas fluorescens)

***OVW: Olive vegetative water 
Table (6): Effect of converted olive mill wastes to compost tea with microorganisms' treatments on some vegetative growth parameters of Manzanillo olive cultivar during 2013 and 2014 seasons.

\begin{tabular}{|l|c|c|c|c|c|c|}
\hline \multirow{2}{*}{ Treatments } & \multicolumn{2}{|c|}{ Shoot length $(\mathbf{c m})$} & \multicolumn{2}{c|}{ No. of leaves/meter } & \multicolumn{2}{c|}{ Leaf area $\left(\mathbf{c m}^{2}\right.$} \\
\cline { 2 - 7 } & $\mathbf{2 0 1 3}$ & $\mathbf{2 0 1 4}$ & $\mathbf{2 0 1 3}$ & $\mathbf{2 0 1 4}$ & $\mathbf{2 0 1 3}$ & $\mathbf{2 0 1 4}$ \\
\hline Control & $23.13 \mathrm{~d}$ & $25.53 \mathrm{~d}$ & $115.60 \mathrm{~g}$ & $123.81 \mathrm{e}$ & $3.75 \mathrm{a}$ & $3.69 \mathrm{a}$ \\
\hline$*$ CT & $26.43 \mathrm{c}$ & $25.93 \mathrm{~d}$ & $131.62 \mathrm{f}$ & $136.90 \mathrm{~d}$ & $3.52 \mathrm{a}$ & $3.51 \mathrm{a}$ \\
\hline CT + **microorganisms & $31.71 \mathrm{a}$ & $33.45 \mathrm{a}$ & $168.15 \mathrm{a}$ & $172.50 \mathrm{a}$ & $3.51 \mathrm{a}$ & $3.65 \mathrm{a}$ \\
\hline CT (75\%) +***OVW (25\%) & $29.50 \mathrm{~b}$ & $30.60 \mathrm{~b}$ & $145.10 \mathrm{~d}$ & $150.40 \mathrm{c}$ & $3.54 \mathrm{a}$ & $3.52 \mathrm{a}$ \\
\hline CT (75\%) +OVW (25\%) + microorganisms & $30.11 \mathrm{~b}$ & $33.00 \mathrm{a}$ & $165.44 \mathrm{~b}$ & $160.20 \mathrm{~b}$ & $3.64 \mathrm{a}$ & $3.54 \mathrm{a}$ \\
\hline CT (50\%) + OVW (50\%) & $29.62 \mathrm{~b}$ & $31.50 \mathrm{~b}$ & $150.33 \mathrm{c}$ & $153.10 \mathrm{c}$ & $3.65 \mathrm{a}$ & $3.66 \mathrm{a}$ \\
\hline CT (50\%) + OVW (50\%) + microorganisms & $27.62 \mathrm{c}$ & $28.13 \mathrm{c}$ & $139.80 \mathrm{e}$ & $139.11 \mathrm{~d}$ & $3.76 \mathrm{a}$ & $3.70 \mathrm{a}$ \\
\hline
\end{tabular}

Means having the same letter(s) within the same column are not significantly differ at the probability of $5 \%$ level according to Duncan's Multiple Range Test.

*CT: Compost tea

Table (7): Effect of converted olive mill wastes to compost tea with microorganisms treatments on leaf minerals contents of Manzanillo olive cultivar during 2013 and 2014 seasons.

\begin{tabular}{|l|c|c|c|c|c|c|}
\hline \multirow{2}{*}{ Treatments } & \multicolumn{2}{c|}{$\mathbf{N}(\boldsymbol{\%})$} & \multicolumn{2}{c|}{ P $(\boldsymbol{\%})$} & \multicolumn{2}{c|}{ K $(\boldsymbol{\%})$} \\
\cline { 2 - 7 } & $\mathbf{2 0 1 3}$ & $\mathbf{2 0 1 4}$ & $\mathbf{2 0 1 3}$ & $\mathbf{2 0 1 4}$ & $\mathbf{2 0 1 3}$ & $\mathbf{2 0 1 4}$ \\
\hline Control & $1.40 \mathrm{f}$ & $1.37 \mathrm{~g}$ & $0.51 \mathrm{a}$ & $0.53 \mathrm{a}$ & $1.13 \mathrm{~g}$ & $1.42 \mathrm{~g}$ \\
\hline *CT & $1.51 \mathrm{e}$ & $1.55 \mathrm{f}$ & $0.52 \mathrm{a}$ & $0.51 \mathrm{a}$ & $1.64 \mathrm{f}$ & $1.59 \mathrm{f}$ \\
\hline CT + **microorganisms & $1.60 \mathrm{~b}$ & $1.70 \mathrm{~b}$ & $0.52 \mathrm{a}$ & $0.53 \mathrm{a}$ & $1.67 \mathrm{c}$ & $1.62 \mathrm{c}$ \\
\hline CT (75\%) +***OVW (25\%) & $1.53 \mathrm{~d}$ & $1.62 \mathrm{e}$ & $0.51 \mathrm{a}$ & $0.52 \mathrm{a}$ & $1.65 \mathrm{e}$ & $1.61 \mathrm{~d}$ \\
\hline CT (75\%) +OVW (25\%)+ microorganisms & $1.65 \mathrm{a}$ & $1.77 \mathrm{~b}$ & $0.53 \mathrm{a}$ & $0.50 \mathrm{a}$ & $1.70 \mathrm{~b}$ & $1.64 \mathrm{~b}$ \\
\hline CT (50\%) + OVW (50\%) & $1.58 \mathrm{c}$ & $1.66 \mathrm{~d}$ & $0.52 \mathrm{a}$ & $0.51 \mathrm{a}$ & $1.66 \mathrm{~d}$ & $1.60 \mathrm{e}$ \\
\hline CT (50\%) + OVW (50\%) + microorganisms & $1.66 \mathrm{a}$ & $1.80 \mathrm{a}$ & $0.52 \mathrm{a}$ & $0.52 \mathrm{a}$ & $1.73 \mathrm{a}$ & $1.66 \mathrm{a}$ \\
\hline
\end{tabular}

Means having the same letter(s) within the same column are not significantly differ at the probability of $5 \%$ level according to Duncan's Multiple Range Test.

*CT: Compost tea **Microorganisms: (Serratia marcescens and Pseudomonas fluorescens)

***OVW: Olive vegetative water

bio-enriched compost tea to improve the absorption and translocation of N, P and $\mathrm{K}$ by leaves tissues. Besides, their contents from considerable amount of soluble mineral nutrients are readily available for the plant uptake. Various studies confirmed the benefitial effect of compost tea on the plant due its direct nutrients supplying and or its microbial functions (Aloran, 2004). Also, these findings are in agreement with the studies reported by Bardi and Malusa, (2012), who mentioned that the positive influence of microorganisms on nutrient uptake is well established. Esitken et al. (2003), Paredes et al. (2005), Tartoura et al. (2005) and Pant et al. (2009) proved that, Serratia marcescens and Pseudomonas fluorescensare were capable of producing IAA and cytokine, have $\mathrm{N}_{2}$-fixing capacity, and M3 has phosphate- solubilizing capacity. Recently, OVW and OPW are known to increase soil organic matter and the concentrations of essential inorganic elements for plant growth resulting in enhanced soil fertility.

\subsection{Flowering parameters}

\subsubsection{Flowering dates and duration of flowering}

As shown in Table (8), all the investigated trees differed in their flowering dates and flowering period. The blooming duration varied between 10-12 days in the control and other treatments. It was 11 days in the trees that received farm fertilization and other treatments without OVW application (except for $75 \%$ CT $+25 \%$ OVW with or without microorganisms). While, the duration of flowering reached 12 days $\left(1^{\text {st }}\right.$ season) in the treatments that received $50 \%$ of $\mathrm{CT}+50 \%$ OVW with or without microorganism. In general, the duration of flowering differed from one season to another. These results agree with the observation of Shereen et al., (2011) on Manzanillo olive trees. 
Table (8): Effect of converted olive mill wastes to compost tea with microorganisms treatments on flowering dates of Manzanillo olive cultivar during 2013 and 2014 seasons.

\begin{tabular}{|l|c|c|c|c|c|c|}
\hline \multirow{2}{*}{ Treatments } & \multicolumn{2}{c|}{ Beginning } & of flowering & \multicolumn{2}{c|}{ End of flowering } & \multicolumn{2}{c|}{ Duration of flowering } \\
\cline { 2 - 7 } & $\mathbf{2 0 1 3}$ & $\mathbf{2 0 1 4}$ & $\mathbf{2 0 1 3}$ & $\mathbf{2 0 1 4}$ & $\mathbf{2 0 1 3}$ & $\mathbf{2 0 1 4}$ \\
\hline Control & $20 \mid 3$ & $16 \mid 3$ & $30 \mid 3$ & $26 \mid 3$ & 11 days & 11 days \\
\hline$*$ CT & $20 \mid 3$ & $16 \mid 3$ & $30 \mid 3$ & $26 \mid 3$ & 11 days & 11 days \\
\hline CT + **microorganisms & $20 \mid 3$ & $16 \mid 3$ & $30 \mid 3$ & $26 \mid 3$ & 11 days & 11 days \\
\hline CT (75\%) + ***OVW (25\%) & $23 \mid 3$ & $20 \mid 3$ & $1 \mid 4$ & $30 \mid 3$ & 10 days & 11 days \\
\hline CT (75\%) + OVW (25\%) +microorganisms & $23 \mid 3$ & $20 \mid 3$ & $1 \mid 4$ & $30 \mid 3$ & 10 days & 11 days \\
\hline CT (50\%) + OVW (50\%) & $25 \mid 3$ & $23 \mid 3$ & $5 \mid 4$ & $1 \mid 4$ & 12 days & 10 days \\
\hline CT (50\%) + OVW (50\%) + microorganisms & $25 \mid 3$ & $23 \mid 3$ & $5 \mid 4$ & $1 \mid 4$ & 12 days & 10 days \\
\hline
\end{tabular}

*CT: Compost tea ** Microorganisms :(Serratia marcescens and Pseudomonas fluorescens) ***OVW: Olive vegetative water

\subsubsection{Flowering characteristics}

Data in Table (9) exerted that there was a convergence between the trees which have been treated with $75 \%$ of $\mathrm{CT}+25 \%$ OVW+ microorganisms and $50 \%$ of CT $+50 \%$ OVW+ microorganisms in the inflorescence length and the number of inflorescence /meter, that showing the most pronounced significant increase in both seasons. Regarding perfect flowers (\%), the values varied from $(41.43 \& 47.93 \%)$ in the control to reach $(68.20 \& 68.60 \%)$ in $50 \%$ of $\mathrm{CT}+50 \%$ OVW+ microorganisms treatment, that was true in the $1^{\text {st }}$ and the $2^{\text {nd }}$ seasons, respectively. These results are in a parallel with (Fayed, 2010) who found that all the parameters of length of inflorescences, number of flowers per meter and sex ratio were significantly increased due to the treating of olive trees with enriched compost.

\subsection{Fruit set, yield and fruit oil content}

The analysis of variance in Table (10) corroborated that, the treated trees with $50 \%$ of $\mathrm{CT}+50 \%$ OVW+ microorganisms tend to have the highest significant percentage of fruit set (28.73 and 31.34) and yield (29.13 and 31.20 $\mathrm{kg} /$ tree) compared with the control (14.66 and 18.26) (14.94 and $20.35 \mathrm{~kg} /$ tree) in both seasons, respectively. The present results are in harmony with those obtained by (Halil et al., 2011) who reported that application of bacterial strains of Pseudomonas and Serratia during full bloom is thought to have a positive effect on fruit set, Meanwhile, Di-Giovacchino et al. (2002) and Altieri and Qlessandro 2008) reported that, using OVW promoted the yield of olive trees. Also, incubation process with microorganisms to the liquid bio-fertilizer (compost + olive pomace +olive vegetable water) could be recommended as liquid application bio-fertilizer for fertigation which apply both water and nutrient into crops at the same time and reduce water and nutrient losses; that led to improve soil fertility and crop growth, while reducing nutrient leaching into the ground water (Bres, 2009). The response to fruit oil content $(\%)$ in dry weight to different rates of compost tea is shown in Table (10). Data exerted that fruit oil content of Manzanillo cv. varied from 28.66 to $32.15 \%$ in the first season, and from 27.25 to $30.91 \%$ in the second season. Adding enriched CT extracted by $50 \%$ of compost tea+ $50 \%$ olive vegetable water gave the highest oil content (\%), while the control treatment was the least in both studied seasons. These results are in a line with (El-Hassani et al. (2010) who pointed that increasing oil content in comparison with the control as a result of application of olive mill waste water as an amendment for menthaspicata $\mathrm{L}$.

\subsection{Fruit physical properties}

\subsubsection{Fruit length, diameter and weight}

Data in Table (11) showed significant increase in fruit physical traits due to different applications of compost tea. In this concern, the maximum fruit length, diameter and weight associated with CT + microorganism and $75 \%$ of CT $+25 \%$ OVW+ microorganisms) in the two studied seasons as compared with other treatments. However, the minimum values were obtained by the control treatment.

\subsubsection{Stone length, diameter and weight}

The overall tends in the effect of tested treatments were obtained in Table (12). Data revealed that the trees that have been treated with the mixture of $75 \%$ of compost tea with $25 \%$ OVW and microorganisms gave the highest stone length and stone weight. While, there were no statistically differences between the treatments in the stone weight records in both seasons. 
Table (9): Effect of converted olive mill wastes to compost tea with microorganisms treatments on flowering characteristics of Manzanillo olive cultivar during 2013 and 2014 seasons.

\begin{tabular}{|c|c|c|c|c|c|c|}
\hline \multirow{2}{*}{ Treatments } & \multicolumn{2}{|c|}{ Length of inf. $(\mathrm{cm})$} & \multicolumn{2}{|c|}{ No. of inf. /meter } & \multicolumn{2}{|c|}{ Perfect flower (\%) } \\
\hline & 2013 & 2014 & 2013 & 2014 & 2013 & 2014 \\
\hline Control & $1.51 \mathrm{f}$ & $1.37 \mathrm{f}$ & $75.66 \mathrm{~d}$ & $77.20 \mathrm{e}$ & $41.43 \mathrm{~g}$ & $47.93 \mathrm{~g}$ \\
\hline *CT & $1.53 \mathrm{e}$ & $1.55 \mathrm{e}$ & $53.41 \mathrm{e}$ & $61.72 \mathrm{f}$ & $51.37 \mathrm{f}$ & $61.73 \mathrm{e}$ \\
\hline $\mathbf{C T}+* *$ microorganisms & $1.58 \mathrm{~d}$ & $1.61 \mathrm{~d}$ & $81.67 \mathrm{~b}$ & $80.87 \mathrm{~d}$ & $55.37 \mathrm{e}$ & $63.53 \mathrm{c}$ \\
\hline CT $(75 \%)+* * *$ OVW $(25 \%)$ & $1.60 \mathrm{c}$ & $1.66 \mathrm{c}$ & $79.54 \mathrm{c}$ & $81.33 \mathrm{~d}$ & $57.47 \mathrm{~d}$ & $58.80 \mathrm{f}$ \\
\hline CT $(75 \%)+$ OVW $(25 \%)+$ microorganisms & $1.75 \mathrm{a}$ & $1.74 \mathrm{a}$ & $84.00 \mathrm{a}$ & $84.66 \mathrm{~b}$ & $66.13 \mathrm{~b}$ & $64.17 \mathrm{~b}$ \\
\hline CT $(50 \%)+$ OVW (50\%) & $1.65 \mathrm{~b}$ & $1.70 \mathrm{~b}$ & $83.56 \mathrm{a}$ & $82.83 \mathrm{c}$ & $59.00 \mathrm{c}$ & $62.17 \mathrm{~d}$ \\
\hline CT $(50 \%)+$ OVW $(50 \%)+$ microorganisms & $1.77 \mathrm{a}$ & $1.75 \mathrm{a}$ & $84.59 \mathrm{a}$ & $85.43 \mathrm{a}$ & $68.20 \mathrm{a}$ & $68.60 \mathrm{a}$ \\
\hline
\end{tabular}

Means having the same letter(s) within the same column are not significantly differ at the probability of $5 \%$ level according to Duncan's Multiple Range Test.

*CT: Compost tea ** Microorganisms :(Serratia marcescens and Pseudomonas fluorescens) ***OVW: Olive vegetative water

Table (10): Effect of converted olive mill wastes to compost tea with microorganisms' treatments on fruit set, yield and oil content of Manzanillo olive cultivar during 2013 and 2014 seasons.

\begin{tabular}{|c|c|c|c|c|c|c|}
\hline \multirow{2}{*}{ Treatments } & \multicolumn{2}{|c|}{ Fruit set $(\%)$} & \multicolumn{2}{|c|}{ Yield/ tree $(\mathrm{Kg})$} & \multicolumn{2}{|c|}{ Fruit oil content (DW) \% } \\
\hline & 2013 & 2014 & 2013 & 2014 & 2013 & 2014 \\
\hline Control & $14.66 \mathrm{e}$ & $18.26 \mathrm{~d}$ & $14.94 \mathrm{~g}$ & $20.35 \mathrm{f}$ & $28.66 \mathrm{e}$ & $27.25 \mathrm{~d}$ \\
\hline$* \mathbf{C T}$ & $22.38 \mathrm{c}$ & $23.95 \mathrm{c}$ & $16.25 \mathrm{f}$ & $22.50 \mathrm{e}$ & $29.25 \mathrm{~d}$ & $28.63 \mathrm{c}$ \\
\hline CT $+* *$ microorganisms & $25.46 \mathrm{~b}$ & $28.99 \mathrm{~b}$ & $21.15 \mathrm{e}$ & $26.63 \mathrm{c}$ & $30.91 \mathrm{c}$ & $29.11 \mathrm{~b}$ \\
\hline CT $(75 \%)+* * *$ OVW $(25 \%)$ & $21.33 \mathrm{~d}$ & $25.90 \mathrm{c}$ & $24.37 \mathrm{c}$ & $26.50 \mathrm{c}$ & $30.72 \mathrm{c}$ & $28.74 \mathrm{c}$ \\
\hline CT $(75 \%)+$ OVW $(25 \%)+$ microorganisms & $27.90 \mathrm{a}$ & $30.11 \mathrm{ab}$ & $28.60 \mathrm{~b}$ & $29.87 \mathrm{~b}$ & $31.09 \mathrm{~b}$ & $30.50 \mathrm{a}$ \\
\hline CT $(50 \%)+$ OVW $(50 \%)$ & $20.85 \mathrm{~d}$ & $27.55 \mathrm{~b}$ & $23.24 \mathrm{~d}$ & $25.57 \mathrm{~d}$ & $31.33 \mathrm{~b}$ & $29.44 \mathrm{~b}$ \\
\hline CT $(50 \%)+$ OVW $(50 \%)+$ microorganisms & $28.73 \mathrm{a}$ & $31.34 \mathrm{a}$ & $29.13 \mathrm{a}$ & $31.20 \mathrm{a}$ & $32.15 \mathrm{a}$ & $30.91 \mathrm{a}$ \\
\hline
\end{tabular}

Means having the same letter(s) within the same column are not significantly differ at the probability of $5 \%$ level according to Duncan's Multiple Range Test.

*CT: Compost tea

***OVW: Olive vegetative water

** Microorganisms (Serratia Marcescens \& Pseudomonas Fluorescens)

Table (11): Effect of converted olive mill wastes to compost tea with microorganisms treatments on fruit dimensions (cm) and weight (g) of Manzanillo olive cultivar during 2013 and 2014 seasons.

\begin{tabular}{|c|c|c|c|c|c|c|}
\hline \multirow[t]{2}{*}{ Treatments } & \multicolumn{2}{|c|}{ Fruit length $(\mathrm{cm})$} & \multicolumn{2}{|c|}{$\begin{array}{c}\text { Fruit diameter } \\
(\mathrm{cm})\end{array}$} & \multicolumn{2}{|c|}{$\begin{array}{c}\text { Fruit weight } \\
\text { (g) }\end{array}$} \\
\hline & 2013 & 2014 & 2013 & 2014 & 2013 & 2014 \\
\hline Control & $2.35 \mathrm{c}$ & $2.54 \mathrm{~d}$ & $1.72 \mathrm{~d}$ & $1.87 \mathrm{~d}$ & $5.19 \mathrm{c}$ & $4.48 \mathrm{c}$ \\
\hline *CT & $2.50 \mathrm{bc}$ & $2.65 \mathrm{bc}$ & $2.03 \mathrm{a}-\mathrm{c}$ & $2.02 \mathrm{c}$ & $5.53 \mathrm{c}$ & $5.46 \mathrm{ab}$ \\
\hline $\mathbf{C T}+* *$ microorganisms & $2.60 \mathrm{ab}$ & $2.73 \mathrm{ab}$ & $2.12 \mathrm{a}$ & $2.18 \mathrm{a}$ & $6.41 \mathrm{a}$ & $5.60 \mathrm{a}$ \\
\hline CT $(75 \%)+* * *$ OVW $(25 \%)$ & $2.47 \mathrm{bc}$ & $2.55 \mathrm{~d}$ & $1.77 \mathrm{~d}$ & $2.08 \mathrm{bc}$ & $5.70 \mathrm{~b}$ & $5.33 \mathrm{ab}$ \\
\hline CT $(75 \%)+$ OVW (25\%) +Microorganisms & $2.70 \mathrm{a}$ & $2.75 \mathrm{a}$ & $2.06 \mathrm{ab}$ & $2.12 \mathrm{ab}$ & $6.35 \mathrm{a}$ & $5.63 \mathrm{a}$ \\
\hline CT $(50 \%)+$ OVW $(50 \%)$ & $2.37 \mathrm{c}$ & $2.55 \mathrm{~d}$ & $1.97 \mathrm{c}$ & $2.02 \mathrm{c}$ & $5.88 \mathrm{~b}$ & $5.14 \mathrm{~b}$ \\
\hline CT $(50 \%)+$ OVW (50\%) + microorganisms & $2.52 \mathrm{~b}$ & $2.70 \mathrm{ab}$ & $2.06 \mathrm{ab}$ & $1.87 \mathrm{~d}$ & $5.87 \mathrm{~b}$ & $5.60 \mathrm{a}$ \\
\hline
\end{tabular}

Means having the same letter(s) within the same column are not significantly differ at the probability of $5 \%$ level according to Duncan's Multiple Range Test.

*CT: Compost tea ** Microorganisms : (Serratia marcescens and Pseudomonas fluorescens)

***OVW: Olive vegetative water 
Table (12): Effect of converted olive mill wastes to compost tea with microorganisms treatments on stone dimensions (cm) and weight (g) of Manzanillo olive cultivar during 2013 and 2014 seasons.

\begin{tabular}{|l|c|c|c|c|c|c|}
\hline \multirow{2}{*}{ Treatments } & \multicolumn{2}{|c|}{ Stone length $(\mathbf{c m})$} & \multicolumn{2}{c|}{ stone diameter $(\mathbf{c m})$} & \multicolumn{2}{c|}{ Stone weight (g) } \\
\cline { 2 - 7 } & $\mathbf{2 0 1 3}$ & $\mathbf{2 0 1 4}$ & $\mathbf{2 0 1 3}$ & $\mathbf{2 0 1 4}$ & $\mathbf{2 0 1 3}$ & $\mathbf{2 0 1 4}$ \\
\hline Control & $1.63 \mathrm{c}$ & $1.67 \mathrm{ab}$ & $0.84 \mathrm{a}$ & $0.83 \mathrm{a}$ & $0.843 \mathrm{c}$ & $0.811 \mathrm{~b}$ \\
\hline *CT & $1.64 \mathrm{c}$ & $1.67 \mathrm{ab}$ & $0.89 \mathrm{a}$ & $0.84 \mathrm{a}$ & $0.863 \mathrm{ab}$ & $0.841 \mathrm{a}$ \\
\hline CT + **microorganisms & $1.66 \mathrm{a}-\mathrm{c}$ & $1.69 \mathrm{a}$ & $0.95 \mathrm{a}$ & $0.86 \mathrm{a}$ & $0.860 \mathrm{a}-\mathrm{c}$ & $0.846 \mathrm{a}$ \\
\hline CT (75\%) +***OVW (25\%) & $1.65 \mathrm{bc}$ & $1.66 \mathrm{ab}$ & $0.90 \mathrm{a}$ & $0.85 \mathrm{a}$ & $0.845 \mathrm{bc}$ & $0.841 \mathrm{a}$ \\
\hline CT (75\%) +OVW (25\%) + microorganisms & $1.71 \mathrm{a}$ & $1.70 \mathrm{a}$ & $0.98 \mathrm{a}$ & $0.90 \mathrm{a}$ & $0.870 \mathrm{a}$ & $0.845 \mathrm{a}$ \\
\hline CT (50\%) + OVW (50\%) & $1.64 \mathrm{c}$ & $1.64 \mathrm{~b}$ & $0.85 \mathrm{a}$ & $0.85 \mathrm{a}$ & $0.820 \mathrm{~d}$ & $0.840 \mathrm{a}$ \\
\hline CT (50\%) + OVW (50\%) + microorganisms & $1.70 \mathrm{ab}$ & $1.69 \mathrm{a}$ & $0.91 \mathrm{a}$ & $0.86 \mathrm{a}$ & $0.847 \mathrm{bc}$ & $0.848 \mathrm{a}$ \\
\hline
\end{tabular}

Means having the same letter(s) within the same column are not significantly differ at the probability of $5 \%$ level according to Duncan's Multiple Range Test.

*CT: Compost tea

** Microorganisms (Serratia marcescens and Pseudomonas fluorescens)

***OVW: Olive vegetative water

\subsubsection{Flesh weight, flesh/fruit weight $\%$ and flesh/stone ratio}

Data in Table (13) it is evident that, there was a different effect of the treatments during the two studied seasons. Generally, all tested treatments had a significant stimulant effect of flesh /fruit weight (\%) as well as flesh/ stone ratio when compared with the untreated ones (control). Whilst, there were no statically differences between the studied treatments and the control in the flesh weight $(\mathrm{g})$ values in both 2013 and 2014 seasons.

The abovementioned results (Tables $11,12,13)$ imply that, bio-enriched compost tea that mixed with olive vegetable water may provide the trees with maintained micronutrients and growth factors, which improve the photosynthesis process leading to improve physical properties of fruits which are in agreement with Page et al. ( 2012) who mentioned that applied compost tea and coinoculation with Phanerochate chrysosporium on tomato plants led to increase fruit weight. Moreover, soil microbial activity was generally increased by OVW application which enhanced fruit physical properties (Laor et al., 2011). Also, Georgia et al. (2010) reported an increase in weight of tomato fruit as a result of application olive waste water. According to (Haynes and Swift (1990) and (Noval and Rezk (2009), applying recycling olive oil wastes for the soil improved soil characteristics that led to significant values of fruit quality. Moreover, PGPR strains that produce plant hormones, such as auxins and cytokines, can stimulate plant cell elongation or cell division (Guardiola, 2008).

\subsection{Economic study}

The economic consideration comparative study of olive Manzanillo cultivar in 2013 and 2014 seasons (Table 14) show that Manzanillo

Table (13): Effect of converted olive mill wastes to compost tea with microorganisms treatments on flesh weight (g), flesh /fruit weight (\%), flesh /stone ratio of Manzanillo olive cultivar during 2013 and 2014 seasons.

\begin{tabular}{|l|c|c|c|c|c|c|}
\hline \multirow{2}{*}{ Treatments } & \multicolumn{2}{c|}{ Flesh weight $(\mathbf{g})$} & \multicolumn{2}{c|}{ Flesh /fruit weight $(\boldsymbol{\%})$} & \multicolumn{2}{c|}{ Flesh/ stone ratio } \\
\cline { 2 - 7 } & $\mathbf{2 0 1 3}$ & $\mathbf{2 0 1 4}$ & $\mathbf{2 0 1 3}$ & $\mathbf{2 0 1 4}$ & $\mathbf{2 0 1 3}$ & $\mathbf{2 0 1 4}$ \\
\hline Control & $4.35 \mathrm{a}$ & $3.67 \mathrm{a}$ & $83.76 \mathrm{c}$ & $81.90 \mathrm{~b}$ & $5.16 \mathrm{f}$ & $4.52 \mathrm{~d}$ \\
\hline *T & $4.67 \mathrm{a}$ & $4.62 \mathrm{a}$ & $84.39 \mathrm{bc}$ & $84.60 \mathrm{a}$ & $5.41 \mathrm{e}$ & $5.49 \mathrm{ab}$ \\
\hline CT + **microorganisms & $5.55 \mathrm{a}$ & $4.75 \mathrm{a}$ & $86.58 \mathrm{a}$ & $84.89 \mathrm{a}$ & $6.45 \mathrm{a}$ & $5.62 \mathrm{a}$ \\
\hline CT (75\%) +***OVW (25\%) & $4.86 \mathrm{a}$ & $4.49 \mathrm{a}$ & $85.18 \mathrm{a}-\mathrm{c}$ & $84.22 \mathrm{a}$ & $5.75 \mathrm{~d}$ & $5.34 \mathrm{~b}$ \\
\hline CT (75\%) +OVW (25\%)+ microorganisms & $5.48 \mathrm{a}$ & $4.79 \mathrm{a}$ & $86.30 \mathrm{a}$ & $84.99 \mathrm{a}$ & $6.30 \mathrm{ab}$ & $5.66 \mathrm{a}$ \\
\hline CT (50\%) + OVW (50\%) & $5.06 \mathrm{a}$ & $4.30 \mathrm{a}$ & $86.05 \mathrm{ab}$ & $83.66 \mathrm{ab}$ & $6.17 \mathrm{~b}$ & $5.12 \mathrm{c}$ \\
\hline CT (50\%) + OVW (50\%) + microorganisms & $5.02 \mathrm{a}$ & $4.75 \mathrm{a}$ & $85.57 \mathrm{ab}$ & $84.86 \mathrm{a}$ & $5.93 \mathrm{c}$ & $5.60 \mathrm{a}$ \\
\hline
\end{tabular}

Means having the same letter(s) within the same column are not significantly differ at the probability of $5 \%$ level according to Duncan's Multiple Range Test.

*CT: Compost tea

** Microorganisms: (Serratia marcescens and Pseudomonas fluorescens)

*** OVW: Olive vegetative water 
Table (14): Economic evaluation on Manzanillo olive trees fertilized by different types of converted olive mill wastes to compost tea.

\begin{tabular}{|c|c|c|c|c|c|c|c|c|}
\hline \multirow[b]{2}{*}{ Treatments } & \multirow[b]{2}{*}{$\begin{array}{l}\text { Average } \\
\text { yield } \\
\text { kg/Fed }\end{array}$} & \multirow[b]{2}{*}{$\begin{array}{c}\text { Cross income } \\
\text { /treatment } \\
\text { (EPG/Fed) }\end{array}$} & \multicolumn{4}{|c|}{ Total Cost (EP) } & \multirow{2}{*}{$\begin{array}{l}\text { Total } \\
\text { Cost } \\
\text { (EP) }\end{array}$} & \multirow[b]{2}{*}{$\begin{array}{c}\text { Average } \\
\text { net return } \\
\text { (EP) }\end{array}$} \\
\hline & & & $\begin{array}{c}\text { Fixed } \\
\text { Cost }\end{array}$ & $\begin{array}{c}\text { Cost of } \\
\text { using } \\
\text { compost }\end{array}$ & $\begin{array}{c}\text { Cost of } \\
\text { preparing } \\
\text { compost tea }\end{array}$ & $\begin{array}{c}\text { Cost } \\
\text { of micro- } \\
\text { organism }\end{array}$ & & \\
\hline Control & 2117.4 & 6352.2 & 2300 & 1500 & -------- & -------- & 3800 & 2552.2 \\
\hline$* \mathbf{C T}$ & 2325.0 & 6975.0 & 2300 & 750 & 216 & -------- & 3266 & 3709 \\
\hline $\mathbf{C T}+* *$ microorganisms & 2866.8 & 8600.4 & 2300 & 750 & 216 & 96 & 3362 & 5238.4 \\
\hline $\begin{array}{l}\text { CT (75\%) +***OOVW } \\
(25 \%)\end{array}$ & 3052.2 & 9156.6 & 2300 & 750 & 216 & -------- & 3266 & 5890.6 \\
\hline $\begin{array}{l}\text { CT }(75 \%)+O V W(25 \%) \\
+ \text { microorganisms }\end{array}$ & 3508.2 & 10524.6 & 2300 & 750 & 216 & 96 & 3362 & 7162.6 \\
\hline CT $(50 \%)+$ OVW $(50 \%)$ & 2928.6 & 8785.8 & 2300 & 750 & 216 & --------- & 3266 & 5519.8 \\
\hline $\begin{array}{l}\text { CT }(50 \%)+\text { OVW }(50 \%) \\
+ \text { microorganisms }\end{array}$ & 3619.8 & 10859.4 & 2300 & 750 & 216 & 96 & 3362 & 7497.4 \\
\hline
\end{tabular}

olive trees treated by the mixture of $50 \%$ of compost tea with $50 \%$ OVW and inoculated with microorganisms led to the highest fruit yield $(3619.8 \mathrm{~kg} / \mathrm{Fed})$ which had the highest net return (7497.4 L.E.) followed by CT $(75 \%)+$ OVW $(25 \%)+$ microorganisms treatment as it recorded $3508.2 \mathrm{~kg} / \mathrm{Fed}$. for yield and (7162.6 L.E.) for net return. On the other hand, the control treatment gave the least yield $(2117.4 \mathrm{~kg} / \mathrm{Fed}$.) as well as net return (2552.2 L.E.) in both studied seasons.

\section{Conclusion}

The great role of compost tea (CT) fertilization which prepared from olive wastes (olive vegetable water and olive pomace) and supplemented with microorganisms for Manzanillo olive trees, as they are indispensable for improvement of the nutritional status of the trees and the production of maximum yield and fruit quality, as well as minimizing the cost of production and in turn increasing the income of olive orchard. These treatments are safe, effective way of recycling olive oil wastes as a fertilizer, easily adopted by growers and ecological agricultural system. Therefore, it should be recommended the superiority of application of $50 \%$ of compost tea with $50 \%$ OVW and microorganisms, which gave the best results in yield, fruit quality and achieved the highest net profit in an economic study.

\section{REFERENCES}

AL-Absi K. M. (2010). Growth and biochemical of olives as influenced by irrigation with tread industrial of olive waste water. J. Plant Nutr., 33:1-14.
Aloran A. A. S. (2004). Effect of compost tea fertilization and Rhizobium inoculation on growth and yield of some lenti varieties. M.Sc. Thesis, Fac. Agric., Cairo Univ., Egypt.

Altieri R. and Qlessandro E.A. (2008). Olive orchard with two experimental olive mill wastes mixtures: effects on soil organic carbon, plant growth and yield. Biores. Tech., 99: 8390-8393.

Aly E. A. (2005). Physiological studies on the effect of salt stress on some olive cultivators. Ph., D. Thesis, Fac. Agric., Benha Univ., Egypt.

Ammar E. and Ben R. (1999). Potential horticultural utilization of olive oil processing wastewater. Acta Hort., 474: 741-744.

Aragon J. M. and Palancar M. C. (2001). Imp olive 2000. Present and future of Alpeorujo; Editorial Completeness, S. A., Madrid, Spain.

Aruoma O. I. (2003). Methodological considerations for characterizing potential antioxidant actions of bioactive components in plant foods. Mutation ResearchFundamental and Molecular Mechanisms of Mutagenesis 523, 9-20.

Association of Official Agricultural Chemists (A.O.A.C.) (1995). Official Methods of Analysis. $15^{\text {th }}$ Ed. Published by Washington, D. C., USA.

Atlas R. M (1995). Handbook of Media for Environmental Microbiology. CRC press, $2^{\text {nd }}$ Ed. Boca Raton, Florida, USA, P.716. 
Bardi L. and Malusa E. (2012). Drought and nutritional stresses in plant: alleviating role of rhizospheric microorganisms. In Abiotic Stress: New Research, N. Haryana and Punj (Eds). Nova Science publishers Inc., Hauppauge, N.Y, USA.1-57.

Berrin S., Ferit C., Birgul E., Ramazan K., Elandsref T., Aylekin B. and Burein C. (2008). The effect of using olive oil vegetation water on some physical and chemical characteristics of soil and nutrient element content of fig (Ficus carica L. cv. Sarilop). International meeting on soil fertility land management and Agroclimatology Turkey, P: 393-402.

Blanquez P., Caminal G., Sarra M., Vicent M. T and Cabarrel X. (2002). Olive waste waters discoloration and detoxification in a bioreactor by the phanerochaete fungus. Biotech. Progress, 18: 660-662.

Bres W. (2009). Estimation of nutrient losses from open fertigation systems to soil during horticultural plant cultivation. Polish J. Environ. Stud., 18(3): 341-345

Brown J. D. and Lilleland D. (1946). Rapid determination of potassium and sodium in plant material and soil extract by flame photometer. Proc. Amer. Soc. Hort. Sci., 48: 341.

Chapman H. D. and Pratt P. F. (1978). Methods of Analysis for Soils, Plants and Waters. Division. of. Agric. Sci., Univ. California, Berkeley, USA. PP:309.

Di-Giovacchino I., Basti C., Costantini N. and Surricchio G. (2002). Olive vegetable water spreading and soil fertilization. Proc. $4^{\text {th }}$ IS on olive growing. Acta Hort., 586: 389-392.

El-Hassani F. Z., Zinedine A., Alaoui M., Merzouki M. and Benlemlih M. (2010). Use of olive mill wastewater as an organic amendment for Menthaspicata L. Indust. Crops \& Products, 32, 343-348.

El-Taweel A. A., Aly A. A. and Soha S. M. (2016). Effect of different irrigation regime and olive vegetative water treated with cyanobacteria on soil chemical properties, growth, yield and fruit quality of olive trees. J. plant production, Mansoura Univ., 7 :271282.

Esitken A. F., Karlidag S. M., Ercisli H. G. and Siddiqui Z.A. (2003). Effect of spraying a growth promoting bacteria on yield and nutrient elements of Apricot trees. Aust. J. Agric. Res., 54: 271-282.
Fayed T. A (2010). Optimizing yield, fruit quality and nutrition status of Roghiani olives grown in Libya using some organic extracts. J. Hort. Sci. Ornamen. Plants, 2: 63-87.

Fouad M. M., Kilany O. A. and El-Said M. E. (1992). Comparative studies on inflorescence emergence, fruit-set and yield of some olive cultivars under Giza conditions. Egypt. J. Apple. Sci., 7:630-644.

Georgia O. G., Zervakis I. and Gaitis F. (2010). Raw and microbiologically detoxified olive mill waste and their impact on plant growth. Terrest. Aqua. Environ. Toxicol. 4 (Special Issue 1): 21-38 Global Science Books

Guardiola J. L. (2008). Increasing citrus fruit size with synthetic auxins. Can J. Microbiol., 47: 77-80.

Ha K. V., Bunemann P. and Marschner E. K. (2008). Dynamic of C,N,P and microbial community composition particulate soil organic matter during residue decomposition . Plant and Soil.,303:253-264.

Halil K. R., Fatih K. E. and Rafet F. S (2011). Effect of plant growth promoting rizobacteria on fruit set, pomological and chemical characteristics, color values, and vegetative growth of sour cherry. Turk. J. Biol., 35: 282-291.

Hargreaves J. C., Adi M. S. and Warman P.R. (2009). Compost tea an effective nutrients amendment in the cultivation of strawberries. J. Sci. Food Agric., 89:390397.

Haynes R. J. and Swift R. S. (1990). Stability of soil aggregates in relation to organic constituents and soil water content. J. Soil Sci., 41: 73-83.

Heady E. O. and Dillon J. L. (1961). Agricultural production functions. Iowa State University Press. Ames, Iowa, U.S.A.

Hegazi E. S. (1970). Studies on growth, flowering and fruiting of some olive seedling strains under Giza condition M.Sc. Thesis., Fac. Agric., Cairo Univ., Egypt.

Ingham E. R. (2005). The compost tea brewing manual, latest methods and Research. $5^{\text {th }} \mathrm{Ed}$. Soil Food Web Inc., Corvallis, Oregon, USA.

Jose L. R., Raul F. G., Rosario H. and Isidro G. C. (2011). Secondary metabolites from species of biocontrol 2 agent Tricoderma. phytochem. Rev. 7:89-123. 
Lefi W. K., Shannak B., Al-Shannag M., Al Anber Z. and Al-Hasan M. (2009). Treatment of olive mill wastewater by chemical and biological processes. Environ. Int'1 ,31, 289-295.

Laor Y., Saadi I., Raviv M., Medina S., ErezReifen D. and Eizenberg H. (2011). Land spreading of olive mill wastewater in Israel: Current Knowledge, practical experience, and future research needs. Israel J. Plant Sci., 59: 39-51.

Malik D. and Sindhu S. (2011). Effect of coinoculation with Pseudomonas sp. on nodulation and plant growth of chickpea Physiol. Mol. Bio. Plants, 17:25- 32.

Malik S.Y., Haddadin H., Omar I.A. and Butros H. (2009). Biological conversion of olive pomace into compost by using Phanerochate chrysosporium and Trichoderma virdi. Biores. Tech., 100, 47734782.

Mofeed A. S. (2002). Effect of picking date on flowering and fruiting of olive trees. M.Sc. Thesis, Fac. Agric., Cairo Univ., Egypt.

Mohammed Kh. I. (2011). Biochemical and microbiological studies on olive industrial liquid wastes. Ph.D thesis Department of Biochemistry, Fac. Agric., Cairo Univ., Egypt.

Murphy J. and Riely J. P. (1962). A modified single dilution method for determination of phosphate in natural water. Ann. Chemi. Acta, 27: p:31-36.

Noval O. A. and Rezk A. 1. (2009). Role of fertilization in improving quality of some agricultural crops. Int'l J. Acad. Res., 1:5965.

Page A. L., Miller R. H. and Keeney D. R. (1982). Methods of soil analysis; part 2. Chemical and microbiological properties $2^{\text {nd }}$ Ed American Soc. of Agronomy (Publ.) Madison, Wisconsin, USA.

Page C., Celano G., Villicco D. and Zaccardelli M. (2012). Effect of co-inoculation with Phanerochate chrysosporium on tomato with whey compost tea applications. Crop product, 83: 80- 86.

Pane C., Celano G., Villecco D. and Zaccardelli M. (2012). Control of botrytis cinerea, Alternaria alternate and Phyrenochateta lycopersici on tomato with compost tea applications. Crop Protec., 38: 80-86.

Pant A. T., Radovich J. K., Hue N. V., Talcott S. T. and Krenek K. A. (2009). Compost tea and its impact on influence growth and mineral nutrients in Pake Choi plants. J. Sci. Food Agric., 89: 2383-2392.

Paraskeva P. A., Papadakis V. G., and Diamadopoulos E. (2006). Technologies of olive waste water treatment. J. Chem. Techno. Biotech., 81: 1475-1485.

Paredes C., Cegarra J., Bernal M. P. and Roig A. (2005). Influence olive mill waste water in composting and impact of compost on swiss chard crop and soil prosperities. Environ. Int'1 , $31:$ 305-312.

Piper C. S. (1950). Soil and plant analysis. Int'l. Sci. Publ., New York,USA, P. 368.

Pregl F. (1945). Quantitative organic microanalysis. $4^{\text {th }} \mathrm{Ed}$, J. A. Churchill. LTD. London, UK., 126-129.

Rallo L. and Fernández-Escobar R. (1985). Influence of cultivar and flower thinning within the inflorescence on competition among olive fruit. J. Amer. Soc. Hort. Sci., 110: 303- 308

Rasouli S. M., Barinand M. H. and Jalili F. T. (2008). The effect of PGPR inoculation on the growth of wheat. International meeting on Soil Fertility Land Management and Agrolimatology. Aydin Turkey, pp:891-898.

Rosa R, Leon L., Merono I., and Rallo L. (2008). Repining time and fruit characteristics of advanced olive selections for oil production. Aust. J. Agric. Res., 59: 46-51.

SAS (1994). SAS Statistics program, Version $6.4^{\text {th }}$ ed. SAA Inst., Cary, NT.

Shereen A. S., El-Taweel A. A. and Al-Khateeb A. (2011). Effect of using olive vegetative water on growth, flowering and yield of Manzanillo olive trees. J. Amer. Sci., 7(9): 501-510.

Snedecor G. W. and Cochran W. G. (1980). Statistical methods. $7^{\text {th }}$ Ed. Iowa State Univ. Press, Ames, Iowa, USA, PP. 507.

Tartoura E. A., El-Saied A. F. and Abdel-Wahab A. M. (2005). Organic farming using a compost tea made from rice straw. Egypt. J. Appl. Sci., 20: 232-249.

Tuck K. L. and Hayball P. J. (2002). Major phenolic compounds in olive oil metabolism and health effects. J. Nutr. Biochem., 13, 636-644.

Van Schouwonburg J.Ch. (1968). International report of soil and plant analysis, Lab. of Soils \& Fertilizers, Agric. Univ., Wageningen, Netherlands. 
Verma J. J., Yaday P. J., Tiwari K. N. and Singh V. (2010). Impact of plant growth promoting rhizobacteria of crop production. Int'l. J. Agric. Res., 5: 954-983.
Vessey J. K. (2003). Plant growth promoting rhizobacteria of biofertilizer. Plant and Soil, 255: 571-586.

$$
\begin{aligned}
& \text { تحويل مخلفات عصر الزيتون إلى شاى الكمبوست بالمعاملة البيولوجية } \\
& \text { وتأثيره على نمو وإنتاجية أشجار الزيتون الكبون المنزانيللو } \\
& \text { شيرين عاطف شاهين ـ أحمد صلاح الدين السودة ـ “عاطف فتح الله محمد عبد الوهاب } \\
& \text { قسم بحوث الزيتون وفاكهة المناطق شبة الجافةـ معهد بحوث البساتين- قومعهد بحوث الأر اضى و المياة و البيئة }
\end{aligned}
$$

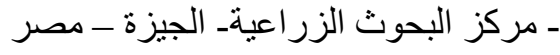

\section{ملخص}

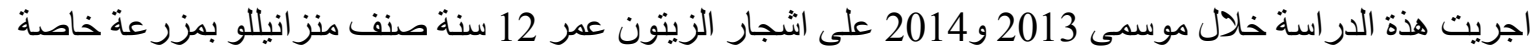

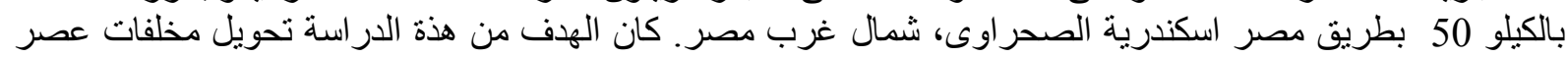

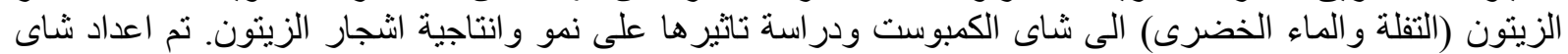

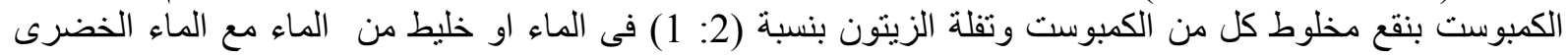

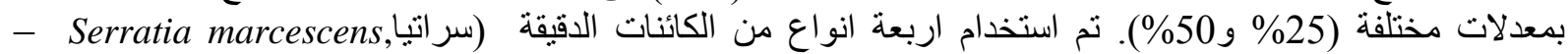

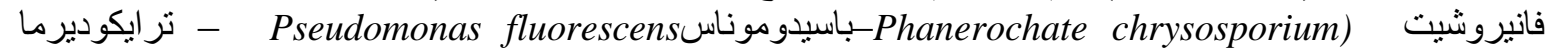
(Trichoderma virdi

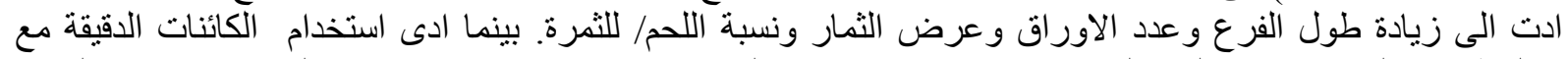

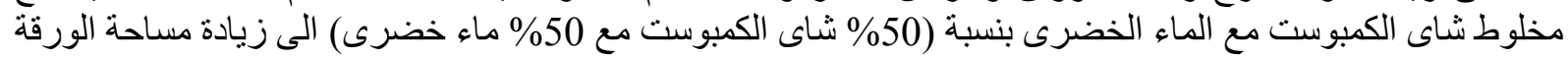

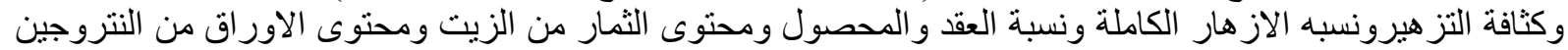

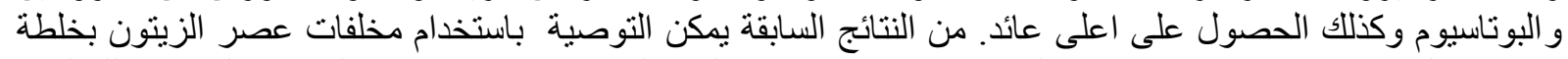

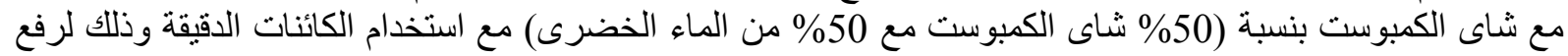

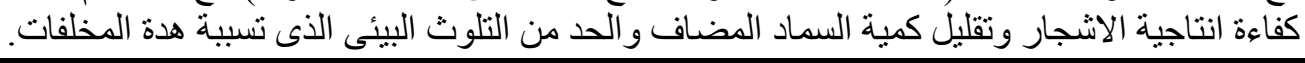

المجلة العلمية لكلية الزراعة - جامعة القاهرة ـ المجلد (68) العدد الرابع (أكتوبر 2017):383-371. 